\title{
Using Mobile Phone Applications in Teaching and Learning Process
}

\section{Mohammed A A Farrah $^{1^{*}}$, Ala' Khalid Abu-Dawood ${ }^{1}$}

* Correspondence:

mfarrah@hebron.edu

${ }^{1}$ English Department, Faculty of Arts, Hebron University, Palestine

Received: 18 November 2017

Accepted: 23 February 2018

Published online: 20 June 2018

\begin{abstract}
This quantitative, qualitative study investigates the usage of mobile phone applications in teaching and learning processes. The study aims to identify the benefits, difficulties, and resolutions of using mobile phone applications. The study was conducted in the English Department at Hebron University at the second semester of the academic years 2015/2016. The study focuses on the Business English course. A questionnaire was used to show the general attitudes of the students towards the effects of using mobile phone applications in the classroom. Interviews were administered to reveal the general attitudes of the students and instructors towards the difficulties and the solutions. The results showed that most students responded positively to using mobile applications in teaching and learning processes. In addition, all students had smart phones, and they used varied brands applications in the learning process. Moreover, the results indicated that students understand and learn better through using the applications.
\end{abstract}

Keywords: mobile phone applications, teaching, learning, SMS, browsing, downloading, camera 


\section{Introduction}

Mobile applications are software designed for mobile devices. Institutions of higher education have shown great interests in using technological devices in education. Numerous mobile phone applications have been increasingly employed in teaching and learning. Consequently, it is a natural outcome for researchers to investigate the effectiveness of such devices on the learning environment and the extent that graduates can reach to fulfill their career expectations and develop $21^{\text {st }}$ century skills. According to constructivism, there is a need to train students to be independent and self-directed (Abuzahra, Farrah, \& Zalloum, 2016). Several studies suggested that mobile devices are invaluable resources in the teaching and learning process as they can help learners and educators to gather information, access content, communicate, and collaborate (Cheung, 2008; Cui et al., 2008; Cui \& Wang, 2008; Farrah, 2011; Ferry, 2008; Helm, Guth, \& Farrah, 2012; Huang, 2010; Khaddage, 2012; Kizito, 2012; Mtega et al., 2012; Prensky, 2004; Suwantarathip \& Orawiwatnakul, 2015).

To sum up, Prensky (2004), Cui and Wang (2008), Kizito (2012), and Wang (2017) assert that using mobile phone applications in teaching and learning provides positive ideas and benefits that motivate students to learn and understand better. In response to the needs of the $21^{\text {st }}$ century skills, Hebron University has identified digital literacy as an important dimension that future teachers should be equipped with. The students of the new generation love technology, and they accept it happily. They usually develop a conspicuous willingness to use mobile phone applications in learning. Accordingly, the researchers conducted this study in order to observe both instructors' and students' perceptions towards the effects of the applications on Business English course students at the English department at Hebron University, Hebron, Palestine.

\subsection{Research Questions}

The current study aimed to answer the following research questions:

1. What is the general attitude towards the benefits of using mobile phone applications in teaching and learning?

2. What are the difficulties of using mobile phone applications in teaching and learning?

3. What are the solutions for the problems caused by using mobile phone applications in teaching and learning?

\subsection{Significance of the Study}

The researchers hope that the results of this paper would be beneficial for other researchers. The research may contain useful information that other researchers may take into consideration while using mobile phone applications at universities. Also, the researchers hope that the study findings will support and develop the uses of the mobile phone applications. They have suggested solutions to the inventors of the applications to update them in a way that suits students. 


\section{Literature Review}

In this section, the researchers aim to review the studies that have been conducted about mobile phones and their applications. Several studies have examined the role of using mobile phones in reinforcing teaching and learning (Cui \& Wang, 2008; Ferry, 2008; Huang, Hwang, \& Chang, 2010; Khaddage et al., 2012; Liaw, Hatala, \& Huang, 2009; Mtega, Bernard, Msungu, \& Sanare, 2012; Rana, 2014; UNESCO, 2012).

Muyinda, Mugisa, and Lynch (2007) have stated that mobile phones are common between people. Recently, the use of mobile phones in communication has evolved; people use them to reinforce teaching and learning. UNESCO (2012) found that the spread of using mobile phones globally and in African, Middle East, and World-wide has reinforced and supported teaching and learning. Huang et al. (2010) have pointed out that the mobile learning applications help students study contents in a convenient way. Also, they help the students to interact with each other at any time and place.

Ferry (2008) has indicated that mobile phones help students to access and adjust web based contents, and they make students cooperate with others. According to Cui and Wang (2008), mobile phones may be used to store and call data such as e-books which make teaching and learning more convenient and successful (as cited in Mtega et al., 2012; Rana, 2014). Khaddage (2012) has concluded that using mobile phone applications helps students to concentrate on their weaknesses, reduce their misconceptions, and reinforce learning. Also, it helps instructors determine students' difficulties and misunderstanding. In addition, instructors can adapt activities, practice teaching, and reinforce assessment and feedback.

There are various applications that can be used in teaching and learning (Cui \& Wang, 2008; Ferry, 2008; Mtega et al, 2012; Kizito, 2012; Rana, 2014). Mobile phone applications can be used for educational practices such as SMS, GPS, camera, browsing, downloading, Bluetooth, Wi-Fi, voice calls, and gaming. Cui and Wang (2008) state that SMS messages are helpful for students to learn foreign languages; they are also important for instructors to connect and communicate with their pupils. According to Ferry (2008) and Cui et al. (2008), there are some browsers that students can use to check e-mails, read books, and watch lectures at any time and place. Students and instructors can also use the browsers to download some materials via their mobile phones. In addition, students and instructors can share and store information resources via Wi-Fi, Bluetooth, or Infrared.

\subsection{Advantages of Using Mobile Applications}

There are some benefits of using SMS applications in teaching and learning (Cheung, 2008; Cui \& Wang, 2008; Kizito, 2012; Mtega et al., 2012; Prensky, 2004; Suwantarathip \& Orawiwatnakul, 2015). According to Cui and Wang (2008), SMS applications have helped students learn foreign languages. Furthermore, text messages can help tutors to communicate with their students. Prensky (2004) has pointed out that SMS messages provide fertile learning opportunities. To elaborate, SMS can elicit the points of view of students, and it can make pupils more aware of the 
event that happens in the class. Cheung (2008) has found that SMS totally motivates interactive class experiments. Suwantarathip (2015) conducted a study that compared the impact of the paper vocabulary exercises inside the classroom with the text messages outside the classroom for 6 weeks. The result was that using SMS messages had positive effects on the participants.

Rana (2012) conducted a study in order to illustrate how mobile phones played an essential role in teaching and learning processes, appoint the mobile phone applications which were used in teaching and learning and identify the web-based activities that helped the students. In order to achieve these objectives, the researcher distributed a questionnaire to 25 teaching staff of different faculties and 100 university students. The results indicated that the use of mobile phone applications were different from one person to another. Some students and teaching staff used text messages and calls more than the applications, while others used the applications more than the text messages and calls. The researcher recommended that the mobile phones applications should be developed.

Cui and Wang (2008) conducted a study in order to identify the devices which are versatile. In other words, they focused on the use of the mobile-based applications in mobile learning with regard to the Chinese educational context. In order to achieve these purposes, the researchers used observation with students. The results indicated that mobile phones were as useful as personal computers; the number of students and instructors who used mobile phones noticeably increased. The recommendation was that mobile phones and their applications should be used more effectively in the future e-pedagogies.

Seol, Sharp, and Kim (2012) conducted a study in order to encourage students to form questions via using mobile phones (SMILE application). In order to achieve this objective, the researchers created the SMILE application and observed 32 fourth and fifth school graders. The results revealed that the students were satisfied with SMILE application, and they were interested in forming questions, and sharing them with each other. Both researchers recommended that SMILE application should be adopted to improve teaching and learning world-wide.

Cheung (2008) conducted a study in order to prove how text messages can abolish the limitations of pencil and paper experiments. In order to achieve this objective, the researcher used observation with school students. The result indicated that the pedagogy of economics was improved in the past decade. The researcher recommended that text messages should be integrated into universities and lectures.

Similarly, Prensky (2004) conducted a study in order to provide knowledge, skills, behaviors, and attitudes that helped students to succeed. In order to achieve this objective, the researcher used observation with students. The study results and recommendations indicated that the price of mobile phones should be cheap.

Moura (2008) conducted a study in order to show the students' perceptions towards mobile-based activities develop learning through using mobiles and motivate collaborative work. In order to achieve these objectives, the researcher administered a questionnaire. The results showed that they 
were motivated and interested in the activity; the students became more aware of the importance of mobile phones in teaching and learning. The researcher recommended that he/she will continue to evaluate the pedagogical implications of mobile phones and the efficacy of mobile learning

Kumar, Tewari, Shroff, Chittamuru, Kam, and Canny (2010) also conducted a study in order to develop learning and teaching for millions of users who are underprivileged in the developing world. In order to achieve this purpose, the researchers used observations with various Indian children. The results showed that mobile phones were similar to personal computers. The researchers recommended that this research needs development to tailor principled perceptions about mobile learning.

There are versatile devices that have facilitated the mobile learning effects (Cui \& Wang, 2008; Prensky, 2004). Cui and Wang (2008) state that internet browsers are now used in mobile phones, specially the third generation protocol. Certain web sites, designed for mobile phones, have become versatile; many students use dictionaries, thesauruses, and encyclopedias on daily basis. Pupils can access the net from their mobile phones and gain the needed instructional materials. In addition, students and tutors can download miscellaneous and limitless materials on their phones. For instance, they can download e-books, music, articles, and instructional materials.

Mtega et al. (2012) conducted a study in order to reinforce teaching and learning. The researchers stated that the mobile phone applications are suitable in teaching and learning, selecting special activities that are convenient for learning via mobile phones, and defining the m-learning limitations at Sokoine University of Agriculture in Tanzania. In order to achieve such objectives, they included 40 university students, interviews, and observation with 5 university teaching staff of four different faculties. The results showed that teaching staff and students used mobile phones for learning and teaching purposes. Students and teaching staff didn't use the same applications, but they used different mobile phone applications. They used messages and calls more than applications. The authors recommended that the specifications of the mobile phones should be studied by the people who usually buy them. The operators of mobile phones should not increase the tariffs of the online services to encourage access to the net.

Additionally, Khaddage et al. (2012) carried out a study in order to identify the university and the instructors' roles in designing proper mobile phone applications, selecting approaches, and administering methods that encourage students to communicate for dynamic output. They did not use a methodology. The results indicated that the integration of mobile applications into education connected educational technology to computer sciences. This integration, between the aforementioned disciplines, was helpful not only for universities but also for secondary and elementary schools. The authors recommended that there're essential issues, difficulties, and thoughts they should focus on because they declared that this paper is broad.

Using mobile phone applications has a positive impact on teaching and learning vocabulary (Basal, Yilmaz, Tanriverdi \& Sari, 2016; Habbash, 2015; Suwantarathip et al., 2015). Basal et al. (2016) conducted a study to show the effectiveness of mobile phone applications on enhancing the 
students' vocabulary reservoir. According to Habbash (2015), the result was neutral; it had the same effect that the traditional way had. The instructors were confused and didn't know how to use the applications in the classroom. Suwantarathip and Orawiwatnakul (2015) stated that there were two groups; the first one used mobile phone applications, but the second one used the traditional way. The result showed that the first group outperformed the second one.

Habbash (2015) conducted a study in order to discover the chance of reinforcing the students' understanding and ineligibility with regard to the English vocabulary items. To achieve the study objectives, a questionnaire was used. The author recommended that instructors should design materials which suit their students.

Basal et al. (2016) carried out a study in order to seek the effectiveness of teaching 40 figurative idioms via a mobile phone application compared to traditional activities for 4 weeks. They used tests to achieve their objectives. The results showed that the experimental group outperformed the control group. The researchers recommended using mobile phone applications in teaching vocabulary.

Elfeky and Masadeh (2016) carried out a study in order to look for the impact of using mobile devices on the on students' achievements and improvements. Their aim was achieved by using the quasi-experimental approach and observation. The result indicated that learning through mobiles had important effects on the students' achievements and skills. The researchers recommended using the applications of mobile phones in classes.

Alqahtani and Mohammad (2015) conducted a study in order to look for "the relationships of behavioral factors and perceived usefulness of using the mobile application 'Say Quran' for learning Quran on students' perceived performance, satisfaction, and behavior" (p.102). The researchers used observation to achieve their aim. Their results indicated that there's a positive relationship between the students' behavior, satisfaction, and performance.

Alkhezzi and Al-Dousary (2016) also conducted a study in order to examine the effects of mobile phone-based learning on the students' vocabulary, grammar, and writing skills. The researchers used observation to achieve their aim. Their results revealed that using mobile phone applications had a positive effect on the students' performance with regard to grammar and vocabulary. It is possible to use such applications outside the classroom to learn more vocabulary items. The researchers recommended that there should be well-tailored applications that encourage students to learn grammar.

Zou and Li (2015) conducted a study in order to investigate how mobile phone applications can be integrated into the process of teaching and learning English outside and inside the classroom. To achieve their aim, they administered questionnaires and interviews. The results showed that mobile applications can be used inside and outside the classroom. 


\subsection{Challenges of Using Mobile Applications}

Khaddage, Cristoph, and Bray (2012) state that there are some challenges that constrain the use of mobile phone applications in the teaching-learning process. To illustrate, mobile phones don't provide wide screens to facilitate reading. Moreover, users need methods and approaches to use the target applications in teaching and learning. For example, "universities and teachers must investigate mobile technologies and devices and their proper applications, and select one device that they see the most commonly used by students, such as the mobile phone" (p. 3). There are other challenges that students and instructors may face while using mobile phones and applications (Cui \& Wang, 2008; Mtega et al, 2012; Rana, 2014,). Cui et al. (2008) showed that mobile phones did not have suitable sizes, so they hindered both instructors and students. The mobile batteries were also limited, so users cannot use them for a long time.

According to Rana (2014) and Mtega et al. (2012), few instructors and students did not know the capacity of their own mobile phones. In addition, some of them did not know that there were other applications in their smart mobile phones, so they only used SMS messages and calls. Additionally, some of them did not know the type of their mobile phones. However, mobile phones had limited storage which prevented students and instructors from downloading and installing materials. The font size of the text was small, so the users faced difficulty in reading the text via mobile phones.

To conclude, the above section reviewed certain studies related to mobile phone applications and e-pedagogies. Some studies were tackled the use of SMS in the process of teaching and learning. Other studies dealt with the role of mobile phones in reinforcing teaching and learning. In addition, other studies dealt with the benefits and the challenges of using mobile applications.

\section{Methodology}

In this section, the researchers describe the design of the study, the participants' characteristics, the instruments, and procedure. Finally, they explain data analysis.

\subsection{Design of the Study}

This study employed a mix methods framework, which consists of quantitative and qualitative approaches. The quantitative data was collected through a questionnaire and the qualitative data was collected through interviews with students and instructors. To validate the findings, a triangulation technique was used to compare the findings obtained from the questionnaires with those of the interview. The following section discusses the participants, instruments, and the data reliability.

\subsection{Participants}

The participants in this study were university students and instructors. They were 33 (27 female, 6 male) at the English Department in Hebron University. They were enrolled in the second semester of the academic year 2015-2016. 


\subsection{Instruments}

Two instruments were used for data collection: questionnaire and interviews. They are explained in detail.

\subsubsection{Questionnaire}

The questionnaire was used in order to show the effects and the availability of the mobile phone applications. The questionnaire was developed by the researchers via using the literature review which was conducted to determine the benefits of the mobile phone applications, their difficulties, and the solutions. After the literature review, a 19-item questionnaire which was convenient for the use of mobile phone applications in teaching and learning was developed by the researchers. The first section of the questionnaire was about the demographic data. To illustrate, gender, GPA, year of study, and some attitudes towards using mobile phone applications were included in this section. The second section contained items about attitudes towards the effects and the uses of mobile phone applications. The items of the questionnaire were written according to two domains - the types of applications used in the classroom and the effects of using mobile phone applications. Likert scale was used in the questionnaire to indicate the degree of agreement and disagreement from 1-5 which were: strongly disagree, disagree, neutral, agree, and strongly agree.

\subsubsection{Validity of the Questionnaire}

The content validity of the questionnaire was examined against the degree to which the scale of items reflected students' attitudes towards smart phone use. The researchers examined the content validity of the instrument by giving it to an expert from the Faculty of Education. Based on his recommendations, the researchers added some items and others were deleted.

\subsubsection{Reliability of the Questionnaire}

The questionnaire reliability was examined and the result showed that the overall Cronbach Alpha Coefficient of the questionnaire was $(\mathrm{r}=0.75 .5)$, indicating a good degree of internal consistency. This means that the questionnaire was a reliable instrument.

\subsubsection{Administration of the Questionnaire}

A 19-item questionnaire was distributed by the end of the second semester of the academic year $2015 / 2016$. The questionnaire was distributed to the students to investigate their attitudes towards the effects and the uses of mobile phone applications in English for Business Course. The number of the questions filled was 33. Quantitative data was analyzed statistically by using the SPSS program version 22.

\subsection{Interviews}

The researchers conducted interviews with three instructors and five students at Hebron University during the second semester of the academic year 2015/2016. The aim of the interviews was to measure students' and instructors' attitudes, the difficulties, and solutions. 


\subsubsection{Validity of the Interview Questions}

Valid qualitative research is about credibly representing different interpretations to the readers. According to Kvale (1996), "the issue of what is valid knowledge involves the philosophical question of what is truth" ( $\mathrm{p}, 238)$. One way to promote validity is to employ a strategy known as triangulation. Triangulation allows for a more in-depth inquiry of a concept by bringing together data from different sources. In this study, triangulation was established through the following data collection techniques.

1. Questionnaires

2. Interviews

3. Similar research studies

Using these techniques assists in producing a better research design, and more valid and reliable findings. Mason (2002) opined that triangulation encourages the researcher to approach their research questions from different angles and to explore their intellectual problems in a more rounded, multi-faceted way.

Another way to promote validity is awareness on the part of the interviewer and interviewees. In this study, the interviews with the instructor and the students in English for Business class were planned to provide a deeper understanding of information related to using mobile applications. Both the instructor and the students had an awareness and understanding for the issue under investigation.

\section{Data Collection}

This study was conducted at the English Department at Hebron University at the second semester of the academic years 2015/2016. The study focuses on the Business English course. In order to achieve the objectives of the study, two research instruments were used for data collection: questionnaire and interviews (see Appendix I and II). The questionnaire was used to show the general attitudes of the students towards the effects of using mobile phone applications in the classroom. The interviews were administered to reveal the general attitudes of the students and instructors towards the difficulties and the solutions.

\section{Data Analysis}

The quantitative data were coded, keyed into the SPSS (Statistical Package for the Social Science) version 22, and analyzed. Descriptive statistics were employed to calculate the frequencies, percentages, mean, and standard deviation. The quantitative analysis of the questionnaire data was triangulated with the information obtained from the interviews.

\section{Results}

This section provides the results obtained from analyzing students' responses in the questionnaire. The first section of this elicitation technique reports the results of the demographic data. The 
second section reports the results of the second part of the questionnaire. Finally, the third section reports the results gained from the interviews with the students and instructors.

\subsection{Demographic Data}

This section presents the results of the first section in the Questionnaire: the demographic data which includes gender, academic level, GPA, anxiety, possession of smart phones, and performance.

Table 1. Students' demographic data

\begin{tabular}{|c|c|c|c|c|}
\hline \multicolumn{2}{|l|}{ Variables } & \multirow{2}{*}{$\begin{array}{l}\text { Frequency } \\
6\end{array}$} & \multirow{2}{*}{$\begin{array}{l}\text { Percent } \\
18.2\end{array}$} & \multirow{2}{*}{$\begin{array}{l}\text { Cumulative } \\
\text { Percentage }\end{array}$} \\
\hline Gender & Male & & & \\
\hline & Female & 26 & 81.8 & \\
\hline & Total & 33 & 100 & \\
\hline \multirow[t]{5}{*}{ Level } & Third & 1 & 3 & 100 \\
\hline & Year & & & \\
\hline & Fourth & 32 & 97 & \\
\hline & Year & & & \\
\hline & Total & 33 & 100 & \\
\hline \multirow[t]{3}{*}{ GPA } & $70-79$ & 18 & 54.5 & 100 \\
\hline & $80-89$ & 15 & 45.5 & \\
\hline & Total & 33 & 100 & \\
\hline \multirow{2}{*}{$\begin{array}{l}\text { When the instructor asks me to learn via mobile } \\
\text { phone applications, I become nervous. }\end{array}$} & Yes & 10 & 30.3 & 100 \\
\hline & No & 23 & 69.7 & \\
\hline \multirow[t]{2}{*}{ I have a smart mobile phone. } & Total & 33 & 100 & \\
\hline & Yes & 33 & 100 & 100 \\
\hline \multirow{3}{*}{$\begin{array}{l}\text { When I use smart mobile phone applications, I } \\
\text { understand and learn better. }\end{array}$} & No & 0 & 0 & \\
\hline & Total & 33 & 100 & \\
\hline & Yes & 25 & 75.8 & 100 \\
\hline
\end{tabular}




\begin{tabular}{lll} 
No & 8 & 24.2 \\
Total & $\mathbf{3 3}$ & $\mathbf{1 0 0}$ \\
\hline
\end{tabular}

Table 1 shows that the bulk of the respondents were females and that reflected the general population of Hebron University in Palestine. The dominating majority of the students 26 (81.8\%) were females, 6 (18.2\%) were males. Regarding their academic level, 1 (3\%) student was in her third year, and the rest of the students $32(97 \%)$ were in the fourth year. Regarding their Grade Point Average (GPA), 18 (54.5\%) students got an average ranging between 70-79, and the rest of the students 15 (45.5) got an average ranging between 80-89.

Regarding anxiousness, 10 (30.3\%) students reported that they become nervous and the rest (23) (69.7\%) indicated that they do not become nervous while using smart phones to learn. All of the students reported that they have smart mobile phones. Finally, when asked if they understand better when they use mobile phones, the majority of the students 25 (75.85) answered that they understand better and the rest answered that they do not understand better.

Question one: What is the general attitude towards the benefits of using mobile phone applications in teaching and learning?

Descriptive statistics were calculated for all the questionnaire items to examine the attitudes of the English for Business course students towards the benefits of using mobile phone applications in teaching and learning.

Table 2. Descriptive statistics (Means and Standard Deviations) for the different benefits, difficulties, methods, and solutions of using mobile phone applications.

\begin{tabular}{|c|c|c|c|c|}
\hline No & Item & No & Mean & SD \\
\hline 19 & $\begin{array}{l}\text { I use Opera Mini, Internet Explorer, Mozilla fire fox, } \\
\text { Opera and Google chrome applications to browse online } \\
\text { such as e-mail, real materials and lectures. }\end{array}$ & 33 & 4.2 & .83 \\
\hline 15 & $\begin{array}{l}\text { Using mobile phone applications makes me enjoy } \\
\text { learning. }\end{array}$ & 33 & 3.9 & .70 \\
\hline 7 & $\begin{array}{l}\text { I use mobile phone applications to contact with my } \\
\text { colleagues through using Facebook, Twitter, and SMS } \\
\text { and so on. }\end{array}$ & 33 & 3.9 & 1.03 \\
\hline 3 & $\begin{array}{l}\text { Using mobile phone applications in learning is } \\
\text { convenient. }\end{array}$ & 33 & 3.9 & .46 \\
\hline
\end{tabular}


$\begin{array}{llllllll}2 & \text { Using mobile phone applications in learning helps } & 33 & 3.8 & .46\end{array}$ students access the content of learning.

$\begin{array}{llllll}6 & \text { Using mobile phone applications in learning helps me } & 33 & 3.8 & .83\end{array}$ store and call data.

$\begin{array}{lllll}18 & \text { Using mobile phone applications is a convenient tool for } & 33 & 3.75 & .74\end{array}$ meaningful learning.

$\begin{array}{llllll}1 & \text { Using mobile phone applications in learning strengthens } & 33 & 3.75 & .53\end{array}$ knowledge retention.

$\begin{array}{llllll}16 & \text { Using mobile phone applications in learning motivates me } & 33 & 3.7 & .83\end{array}$ to study hard.

$\begin{array}{lllll}14 & \text { I use communication applications to communicate, share } & 33 & 3.6 & 1.18\end{array}$ and discuss data through Facebook and Skype.

$\begin{array}{llllllll}8 & \text { Using mobile phone applications in learning is } & 33 & 3.55 & .83\end{array}$ diversionary for me.

$\begin{array}{lllll}12 & \text { I use collaboration applications to share documents and } & 33 & 3.55 & .51\end{array}$ files such as Google applications.

11 Though there are educational applications in my phone, I $\begin{array}{llll}33 & 3.4 & .92\end{array}$ download extra applications.

$\begin{array}{lllllll}17 & \text { Using mobile phone applications is consistent with } & 33 & 3.3 & .70\end{array}$ language/literature learning courses.

$\begin{array}{llllll}4 & \text { Using mobile phone applications in learning reinforces } & 33 & 3.3 & .74\end{array}$ what I'm weak in.

$\begin{array}{lllll}13 & \text { I use coordination applications to get information about } & 33 & 3.3 & 1.35\end{array}$ my assignments and date class organization such as Twitter.

$\begin{array}{lllll}5 & \text { Using mobile phone applications in learning reduces my } & 33 & 3.15 & .51\end{array}$ misconceptions.

$\begin{array}{lllll}9 & \text { I use my phone just for texts and calls. } & 33 & 2 & 1.16\end{array}$

$\begin{array}{lllll}10 & \text { I do not know my mobile phone's type. } & 33 & 1.6 & .35\end{array}$ 
Table 2 shows that the students had positive attitudes regarding the use of mobiles in the process of learning. The item that got the highest agreement is item number 19. This means that most students strongly agreed that they normally use versatile browsers when they browse for materials and other things. This was in line with the findings of Mtega (2012), Khaddage (2012), and Rana (2012).

Other items that scored high agreements were $(15,7,3,2, \& 6)$. The students majorly used mobile phone applications in order to connect with their classmates through using Facebook, twitter, and SMS as shown in item 7. This was in line with other studies that showed the students' willingness to use social media to connect with others (Cheung, 2008; Khaddage, 2012; Mtega, 2012; Rana, 2012; Seol, 2012). The students reported that they like to use mobile phone applications because they will enjoy learning as perceived in item 15 . This reflected several studies that investigated the "interest" dimensions in mobile phone-based learning (Khaddage, 2012; Mtega, 2012).

The least agreed with items were number 9 and 10. This means that the students did not agree that they use their phone just for text messages and calls. This reflected the perceptions of Cui (2008), Cheung (2008), Mtega (2012), and Rana (2014) that the students use their mobiles in various mobile applications.

\subsection{The Results of the Interviews}

\subsubsection{The Attitudes of the Students and Instructors towards Using the Applications}

The researchers interviewed some instructors and students. As mentioned above, three instructors and five students were interviewed. They were asked them the following questions:

1. What's your attitude towards using mobile phone applications in teaching and learning?

The attitudes of the instructors towards using mobile phone applications were positive and similar to some extent. There was no contradiction among them. First of all, there was an agreement among the interviewed instructors that mobile phone applications are not popular in Palestine, both in schools and universities, because not all students have smart phones. However, they pointed out that if all students have smart phones, they can use the applications for educational purposes. Moreover, they added that smart phones are necessary, needed, and valuable sources for instructors and students. Finally, they welcomed using mobile phone applications and advised other instructors and students to use them in the classroom. However, students should use them in a way that does not distract others.

On the other hand, there were five students who showed their attitudes towards using mobile phone applications in teaching and learning. Most of the students pointed out that they prefer using smart phones applications because they are meaningful, especially for EFL learners who always need such applications. Furthermore, they declared that they like using smart phone applications due to their educational benefits. They explained that using smart phone applications has helped them in their academic life. One student stated that he does not use the mobile phone applications though he has a smart phone. 
2. Do you believe that using mobile phone applications are useful or not? Why?

The interviewed instructors mentioned some advantages for using smart phone applications. First, using the different applications is useful because they have a lot of advantages in terms of access to information and convenience, instructors can ask their students to look for meanings at any time. Moreover, they help the students to participate in the learning process. To illustrate, instructors could ask their students to get clichés via the internet; such approach is called "the learner centered approach." They added that using such applications is useful because it helps students to learn a second language easily and these applications are considered a source of information which facilitates access to information. For instance, dictionaries applications are used so much as they help students to look for any meaning, pronunciation, synonyms, antonyms, definitions, and terminology. Furthermore, they added that using smart phone applications is meaningful because it facilitates work, study, access to knowledge, practice and training. Finally, they emphasized the idea that time can be wisely used.

Similarly, the interviewed students listed many advantages for using smart phones applications. The first advantage is that mobile phone applications have helped them access to information quickly and easily. For instance, dictionaries applications such as Longman, Oxford, Dictbox, and Almaany applications usually trigger them to get the meaning of words wherever and whenever they need them. They mentioned that these applications can improve their four language skills. Moreover, the applications help them save time, money, and information. Furthermore, they mentioned that the mobile applications encourage them to share knowledge with each other. Finally, most of the students emphasized that meaningful applications entertain students, enhance their goals, and help them get rid of daily stressful routines.

3. What are the difficulties of using mobile phone applications in learning and teaching processes?

The difficulties that were mentioned by students were similar. One of the students stated that some applications usually need access to the internet in order to benefit from the applications in the learning process, so she deletes some of them because most of the time the internet service is not available. She added that the benefits of the applications depend on the access to the internet. Sometimes, it is not allowed to use the applications classroom exams. Another student said that he had a difficulty to get a smart phone. Furthermore, a student said that there are some applications with a complicated system (internet access, e-mail, and passwords). This prevents students from using applications effectively, such as Duolingo Test. Finally, one student stated that students get distracted because they may chat with friends.

4. What are the solutions for the difficulties that the students face during using mobile phone applications?

The students offered a number of suggestions for the difficulties and the problems they face. The first suggestion is that the internet should be available in any place, especially at Hebron University. The second suggestion is that the inventors of such applications ought to design applications which have easy systems. 


\section{Discussion}

The results of the questionnaire matched the results of the interviews that the researchers synthesized. First of all, the advantages that the students mentioned in the interviews were similar to the advantages the students mentioned in the questionnaire. For instance, most of the students held a positive opinion towards the impact of applications on knowledge retention and support. In addition, five students who were interviewed, stated that the applications normally encourage them to access the content and information; the same perceptions were manifested in the questionnaire. Moreover, the following item was mentioned in both the questionnaire and the interviews; "using mobile phone applications help the student remember and call data." Some interviewed students stated that they usually use the applications to connect with each other.

Additionally, the result of the interviews was similar to what was mentioned in the literature review. On the one hand, one interviewee showed that the applications help her connect with other mates. Moreover, all the students mentioned that such applications help them access to any content they need. As a result, the researchers found out that these results are mentioned in the literature review by other researchers such as Huang et al. (2010) and Ferry (2008).

On the other hand, some of the difficulties, which the target students faced in the experiment, were not similar to other studies. For example, the students faced several obstacles such as the lack of internet access all the time and everywhere. Additionally, some applications have had complicated systems. Thus, they wasted students' time and interrupted their attention. Whereas, the obstacles mentioned in the literature review were that some mobiles' sizes were small, and the batteries of the mobiles are limited. Because the difficulties mentioned by the interviewed students are different from the ones mentioned in the literature review, the solutions that were suggested by the students differ from those of the researchers.

The findings of this study reveal that using mobile applications has solid advantages. This is in agreement with a number of studies. For example, Prensky (2004), Cui and Wang (2008), Kizito (2012), and Wang (2017) assert that using mobile phone applications in teaching and learning provides positive ideas and benefits that motivate students to learn and understand better. Cui and Wang (2008) suggested that mobile applications are helpful for students to learn foreign languages and for instructors to connect and communicate with their pupils.

Abuzahra, Farrah, and Zalloum (2016) emphasize that learning is most active when it occurs as a result of a collaborative effort. Khaddage (2012) stresses that effective learning takes place when the teacher communicates effectively with his students in an enjoyable and convenient learning environment.

The results obtained from the quantitative data and qualitative data indicate that using mobile applications can help learners and educators to gather information, access content, communicate, and collaborate. This is in line with the findings of Cui and Wang (2008), Ferry (2008), and Cheung (2008). Cheung (2008) has found that such environments motivate interactive class experiments. Likewise, Moura (2008) found that mobile-based activities develop learning through using 
mobiles and motivate collaborative work. Similarly, Cui and Wang (2008) reported that mobile phones make teaching and learning more convenient and successful. Finally, the above finding is in agreement with the findings of Mtega (2012) and Khaddage (2012) who suggested that such mobile applications can be as engaging, interesting, and enjoyable.

\section{Conclusion}

In conclusion, using mobile applications and technological resources enables learners to have a comprehensive scope for the learning process in the language classroom, as they expedite a multidisciplinary perception on learning and open new opportunities for learners. In this study, the researchers investigated the students' and instructors' perceptions and attitudes towards the use of mobile applications in the English Department at Hebron University. This study investigated the benefits, difficulties, and the solutions of using mobile phone applications. As the study revealed, mobile applications are likely to present an additional valuable outcome on learning in this challenging, yet fascinating, and motivating learning environment. It's evident from the results of questionnaire and interview that the majority of students have favorable views towards using mobile applications for they involve energetically with such mobile learning applications. They take opportunities to assume their responsibilities to learn in a learner-centered classroom, in a collaborative and interactive manner with their peers and their instructors alike. The results showed that most of the students used mobile phone applications because of easiness of accessibility and flexibility which helped them in the teaching and the learning process. Based on the results of the study, the researchers believe that using mobile applications in teaching and learning process might have a noteworthy effect on the students' academic progress.

\section{Recommendations}

The main purpose of this research paper was to investigate using mobile phone applications in the teaching and learning processes. Universities and instructors will find the results of this paper to be very beneficial as it will help them enhance their understanding of mobile applications use in educational environments. Accordingly, it may help them shape their knowledge for an effective use of mobile applications. The researchers recommended that universities especially Hebron University and its technology instructors should create certain educational applications for all of the courses according to the requests of the department's instructors which are suitable and meaningful for the instructors and students' specializations. Moreover, the researchers recommended that the inventors should make the size of the phone and its text bigger and more convenient for reading and other purposes. In order to make the use of mobile phone applications useful in teaching and learning, tutors who reject using the applications should be encouraged and persuaded to use them. In addition, the researchers recommended that other researchers should do similar studies, and that they may benefit from using it. Also, the researchers recommended that

other researchers review this study as a secondary data in their future studies to develop the study and its results. 


\section{References}

Abuzahra, N., Farrah M., \& Zalloum, S. (2016). Using cartoon in language classroom from a constructivist point of view. Arab World English Journal AWEJ Special Issue on CALL, 3, 229-245 https://ssrn.com/abstract=2822995 or http://dx.doi.org/10.2139/ssrn.2822995

Alkhezzi, F., Al-Dousari, W. (2016). The impact of mobile learning on ESP learners' performance. The Journal of Educators Online, 13(2), 73-101. https://files.eric.ed.gov/fulltext/EJ1106736.pdf

Alqahtani, M., \& Mohammad, H. (2015). Mobile applications' impact on students' performance and satisfaction. TOJET: The Turkish Online Journal of Educational Technology, 14(4), 102-112.

Basal, A., Yilmaz, S., Tanriverdi, A., \& Sari, L. (2016). Effectiveness of mobile applications in vocabulary teaching. Contemporary Educational Technology, 7(1), 47-59. https://eric.ed.gov/?id=EJ1105763

Cheung, S. (2008). Using mobile phone messaging as a response medium in classroom experiments. Journal of Economic Education, 51-67. https://papers.ssrn.com/sol3/papers.cfm?abstract_id=906681

Cui, G., \& Wang, S. (2008). Adopting cell phones in EFL teaching and learning. The University of Southern Mississippi, 1(1), 69-80. doi: 10.18785/jetde.0101.06 http://aquila.usm.edu/jetde/vol1/iss1/6

Elfeky, A., \& Masadeh, T. (2016). The effect of mobile learning on students' achievement and conversational skills. International Journal of Higher doi: $\underline{\text { https://doi.org/10.5430/ijhe.v5n3p20 }}$

Farrah, M. (2011). Online communication and enhancing language skills, motivation, and cultural understanding. The $\begin{array}{llllll}\text { AUC TESOL } & \text { Journal } & \text { Retrieved } & \text { from }\end{array}$ http://www.aucegypt.edu/huss/eli/TESOL/issues/Pages/Home.aspx

Ferry, B. (2008). Using of mobile phones to augment teacher learning in environmental education. Proceedings Ascilite Melbourne, 295-298.

Habbash, M. (2015). Learning English vocabulary using mobile phones: Saudi Arabian EFL instructors in focus. European Scientific Journal, 11(35), 446-457. eujournal.org/index.php/esj/article/download/6808/6535

Helm, F., Guth, S., \& Farrah, M. (2012). Promoting dialogue or hegemonic practice: Power issues in telecollaboration. Language Learning \& Technology, 16(2), 103-127. https://eric.ed.gov/?id=EJ972353

Huang, Y., Hwang, W., \& Chang, G. (2010). Guest editorial-innovations in designing mobile learning applications. Educational Technology \& Society, 13(3), 1-2. https://scholar.lib.ntnu.edu.tw/.../guest-editorial-innovationsin-designing-mobile-lear

Khaddage, F., Christoph, L., \& Bray, E. (2012). Mobile apps integration for teaching and learning, are instructors ready to re-blend? Retrieved on $10^{\text {th }}$ April, 2016. http://www.ericbray.com/wordpress/wpcontent/uploads/2012/12/site2011.pdf

Kizito, N. (2012). Pre testing mathematical concepts with the mobile phone: implications for curriculum design. The international review of research in open and distributed learning, 13(1).

Kumar, A., Tewari, A., Shroff, G., Chittamuru, D., Kam, M., \& Canny, J. (2010). An exploratory study of unsupervised mobile learning in rural India. In CHI "10 Proceedings of the SIGCHI Conference on Human Factors in Computing Systems, 743-752.

Kvale, S. (1996). Interviews: An introduction to qualitative research interviewing. London: Sage. 
Liaw, S., Hatala, M., \& Huang, H. (2009). Investigating acceptance towards mobile learning to assist individual knowledge management: based on activity theory approach. Computers \& Education, 54, $446-454$. doi:10.1016/j.compedu.2009.08.029

Mason, J. (2002). Qualitative researching. London: Sage Publications Ltd.

Moura, A. (2008). Mobile learning with cell phones and mobile flicker: one experience in a secondary school. 1-5. repositorio.uportu.pt/bitstream/11328/466/2/MOBILE\%20LEARNING.2008.pdf

Mtega, W., Bernard, R., Msungu, A., \&Sanare, R. (2012).Using mobile phones for teaching and learning purposes in higher learning institutions: the case of Sokoine University of agriculture in Tanzania. Proceedings and report of the $5^{\text {th }}$ UbuntuNet Alliance annual conference, 118-129.

Muyinda, P. B., Mugisa, E., \& Lynch, K. (2007). M-learning: the educational use of mobile communication devices. Retrieved $\quad 10 \quad$ April 2016. http://cit.mak.ac.ug/iccir/downloads/SREC_07/Paul\%20Birevu\%20Muyinda\%20,\%20Ezra\%20Mugisa\%20, \%20Kathy\%20Lynch_07.pdf

Prensky, M. (2004). What can you learn from a cell phone? - Almost anything! How to use the 1.5 billion computers already in our students' and trainees' pockets to increase learning, at home and around the world. 1-9.

Rana, S. (2014). A study of use of mobile phones for teaching \& learning purpose. International Journal of Science and Research, 3(6), 2765-2767. https://www.ijsr.net/archive/v3i6/MDIwMTQ4MzQ=.pdf

Seol, S., Sharp, A., \& Kim, P. (2012). Stanford mobile inquiry-based learning environment (SMILE): using mobile phones to promote student inquires in the elementary classroom. Retrieved on $8^{\text {th }}$ April, 2016. http://citeseerx.ist.psu.edu/viewdoc/download? doi=10.1.1.218.980\&rep=rep1\&type=pdf

Suwantarathip, O., \& Orawiwatnakul, W. (2015). Using mobile-assisted exercises to support students' vocabulary skill development. TOJET: The Turkish Online Journal of Educational Technology, 14(1), 163-171. http://files.eric.ed.gov/fulltext/EJ1057347.pdf

UNISCO. (2012). Mobile learning for instructors in Africa and the Middle East: Exploring the potentials of mobile technologies to support instructors and improve practices. United Nations Educational, Scientific and Cultural Organization, 1-40.

Wang, B. T. (2017). Designing mobile apps for English vocabulary learning. International Journal of Information and Education Technology, 7(4), 279-283. doi: 10.18178/ijiet.2017.7.4.881

Zou, B., \& Li, J. (2015). Exploring mobile apps for English language teaching and learning. Critical Call Proceedings of the 2015 EUROCALL Conference, volume Dublin: Researchpublishing.net.http://dx.doi.org/10.14705/rpnet.2015.000394 


\section{Appendix I: Questionnaire}

The purpose of this questionnaire is to measure the students and the instructors' attitudes towards the benefits of using mobile phone applications. . Please read the statements carefully and answer PART I, and PART II. Your answers will be kept strictly confidential and anonymous.

PART I: Please, tick $(\checkmark)$ the appropriate box.

\begin{tabular}{|l|l|}
\hline A - Gender: $\square$ Female $\quad \square$ Male \\
\hline B- Year of study: $\quad \square$ Third \\
\hline C- Current GPA: $\square 70-79 \quad \square$ Fourth \\
\hline D- Do you feel nervous when you use mobile phone applications? $\square$ Yes $\square$ No \\
\hline
\end{tabular}

PART II: Indicate the extent to which you agree or disagree with the following statements regarding your views towards the general attitudes of the students of using mobile phone applications by putting a tick $(\checkmark)$ in the appropriate box using the scale given below.

$\begin{array}{ccccc}\text { Strongly Disagree } & \text { Disagree } & \text { Neutral } & \text { Agree } & \text { Strongly agree } \\ 1 & 2 & 3 & 4 & 5\end{array}$

\begin{tabular}{|c|c|c|c|c|c|c|}
\hline No & Item & 1 & 2 & 3 & 4 & 5 \\
\hline 1 & $\begin{array}{l}\text { Using mobile phone applications in learning strengthens knowledge } \\
\text { retention. }\end{array}$ & & & & & \\
\hline 2 & $\begin{array}{l}\text { Using mobile phone applications in learning helps students access } \\
\text { the content of learning. }\end{array}$ & & & & & \\
\hline 3 & Using mobile phone applications in learning is convenient. & & & & & \\
\hline 4 & $\begin{array}{l}\text { Using mobile phone applications in learning reinforces what I'm } \\
\text { weak in. }\end{array}$ & & & & & \\
\hline 5 & $\begin{array}{l}\text { Using mobile phone applications in learning reduces my } \\
\text { misconceptions. }\end{array}$ & & & & & \\
\hline 6 & $\begin{array}{l}\text { Using mobile phone applications in learning helps me store and call } \\
\text { data. }\end{array}$ & & & & & \\
\hline 7 & $\begin{array}{l}\text { I use mobile phone applications to contact with my colleagues } \\
\text { through using Facebook, Twitter, and SMS and so on. }\end{array}$ & & & & & \\
\hline 8 & Using mobile phone applications in learning is diversionary for me. & & & & & \\
\hline 9 & I use my phone just for texts and calls. & & & & & \\
\hline 10 & I do not know my mobile phone's type. & & & & & \\
\hline
\end{tabular}




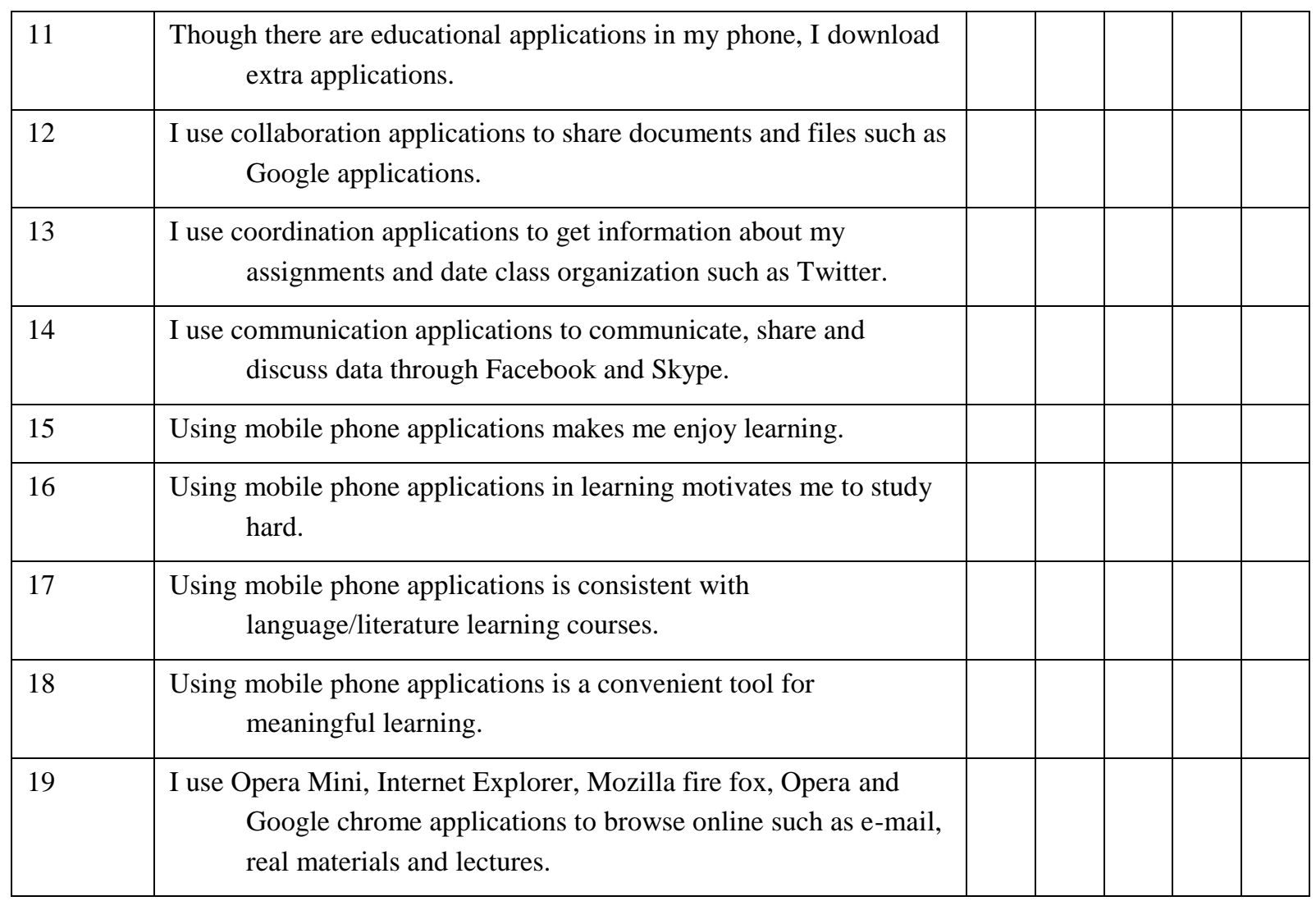




\section{Appendix II: Interview Questions}

1. What's your attitude towards using mobile phone applications in teaching and learning?

2. Do you believe that using mobile phone applications is useful or not? Why?

3. What are the difficulties of using mobile phone applications in learning and teaching processes?

4. What are the solutions for the difficulties that the students face during using mobile phone applications? 